\title{
Allelopathy of Cover Crops on the Germination and Initial Development of Euphorbia heterophylla
}

\author{
Alexandre Bianchini ${ }^{1}$, Pedro Valério Dutra de Moraes ${ }^{1}$, Juliana Domanski Jakubski ${ }^{1}$, \\ Cristiana Bernardi Rankrape ${ }^{1}$, Elyoenay Gadyel ${ }^{1}$, Maira Cristina Schuster ${ }^{2} \&$ Patricia Rossi $^{3}$ \\ ${ }^{1}$ Postgraduate Program in Agroecosystem (PPGSIS), Federal Technological University of Parana, Campus Dois \\ Vizinhos, PR, Brazil \\ 2 Postgraduate Program in Agronomy (PPGAG), Federal Technological University of Parana, Campus Pato \\ Branco, PR, Brazil \\ ${ }^{3}$ Postgraduate Program in Zootecnia (PPGZOO), Federal Technological University of Parana, Campus Dois \\ Vizinhos, PR, Brazil \\ Correspondence: Pedro Valério Dutra de Moraes, Postgraduate Program in Agroecosystem (PPGSIS), Federal \\ Technological University of Paraná, Campus Dois Vizinhos, Km 04, CEP 85660-000, Dois Vizinhos, PR, Brazil. \\ Tel: 55-463-536-8900. E-mail: pedromoraes@utfpr.edu.br
}

$\begin{array}{lcc}\text { Received: May 7, } 2019 & \text { Accepted: June 4, } 2019 & \text { Online Published: August 31, } 2019 \\ \text { doi:10.5539/jas.v11n14p74 } & \text { URL: https://doi.org/10.5539/jas.v11n14p74 }\end{array}$

\begin{abstract}
Cover crop is a important way for weed management in agriculture. The objective of this study was to investigate the effects of aqueous extracts of the aerial part of Avena strigosa, Cichorium intybus, Chenopodium quinoa and Fagopyrum esculentum in different concentrations on the germination and development of Euphorbia heterophylla. The experimental design was completely randomized, in factorial $4 \times 5$ with four replicates. Factor A-aqueous extracts of the aerial part of the cover plants and factor B-concentrations of $0 \%$; $1 \%$, $2.5 \%, 5 \%$ and $10 \%$. A total of $25 \mathrm{E}$. heterophylla seeds, arranged in gerboxes, were used and $15 \mathrm{ml}$ of the extracts were added according to the treatments. The germination test was performed in a growth chamber (BOD) with photoperiod of $12 / 12$ light/dark hours and constant temperature of $25 \pm 1{ }^{\circ} \mathrm{C}$. The data were submitted to analysis of variance by the $\mathrm{F}$ test, a comparison was made between means and the concentration factor of the extracts and the regression analysis. The $C$. quinoa aqueous extracts (10\%) presented greater allelopathic potential than the other extracts in the variables tested for E. heterophylla. C. intybus presented allelophatic potential with results superior to A. strigosa and $F$. esculentum. The $C$. quinoa and $C$. intybus extracts have allelopathic potential when compared to the control with the highest dose $(10 \%)$, interfering mainly in the root portion of E. heterophylla.
\end{abstract}

Keywords: Avena strigosa, Cichorium intybus, Chenopodium quinoa, Fagopyrum esculentum, allelochemical

\section{Introduction}

The culture of soybeans is influenced by several natural and anthropic factors, such as weather interferences, soil fertility, management of natural resources, application of available technologies (Melo \& Souto, 2011), among others, such as the interference generated by weeds.

According to Voll et al. (2008), weeds such as Euphorbia heterophylla (milk weed), Bidens pilosa (beggars tick), Conyza bonariensis (fleabane), among others, are between the main weeds that sprout in soybean crops. In these plants, through the erroneous use of herbicides, resistance has been selected due to pressure selection, that is, the inadequate management of these plants with highly selective herbicides, causing losses of productivity of commercial crops.

Chemical control is the most used method to control weeds, however, more information must be researched at a regional level and presented to the farmers, so they have new alternatives of less pollutant technologies, or the integration of methods in the control of weeds (Lamego et al., 2013).

To decrease the intensity of competition between crops of economic interest and weeds, chemical products are mostly used, which can be applied in conjunction with other control methods. One of these methods is crop 
rotation with the use of cover plants that have allelopathic factors to decrease the incidence and density of weeds and facilitate their handling (Rizzardi \& Silva, 2006).

Among the cover plants with allelopathic potential is oat, which can suppress weeds as cover crops (Trezzi \& Vidal, 2004). The allelopathic potential is associated to the exudation of scopoletin and has an effect on the root growth of some plants (Monteiro \& Vieira, 2002).

Another species with allelopathic potential is Cichorium intybus L. (chicory), however, there are few studies on the allelopathy of this and other species. It is only known that chicory roots are used to produce inulin (Oliveira et al., 2004).

In studies performed in 24 varieties of Chenopodium quinoa seeds (quinoa), in Peru, phenolic composts and flavonoids were found between the different studied quinoa seeds (Valencia et al., 2017). The flavonoids have allelopathic potential on some weeds and cultivated plants.

Fagopyrum tataricum (Buckwheat) can suppress the B. pilosa with soil coverage from $4.0 \mathrm{t} \mathrm{ha}^{-1}$ of dry biomass, reducing the number of emergence, the germination speed index, and the dry mass of the aerial and root parts of the weed (Pacheco et al., 2013). When analyzing the different parts of Fagopyrum esculentum (buckwheat), nine different phenolic acids were identified (Sytar et al., 2014).

Integrated weed management should be implemented by all farmers to minimize the negative impacts of the current production model, which harms the environment and the population as a whole. One of the methods that can be very effective in weed control is the use of cover crops with allelopathic factors, inhibiting the germination and development of undesirable species (Hagemann et al., 2010).

The use of ground cover plants with allelopathic factors can be an important tool, particularly in weed control in agriculture crops. Allelopathy can cause both damage and provide benefits to other plants in its area of influence, through the release of chemical compounds to the environment (Filho, 2002).

The release of these compounds to the environment can occur in several ways, depending on the characteristic and the type of condition this vegetable is subjected to, and can be through volatilization, usually through leaves, root exudations directly into the soil, leaching by rain and dew, and the release by the decomposition of waste (Filho \& Alvez, 2002).

Thus, this study had the objective of investigating the effects of aqueous extracts of the aerial part of different ground cover plants and in different concentrations on the germination and the initial growth of Euphorbia heterophylla.

\section{Material and Methods}

The experiment was performed in the Laboratory of Seed Analyses of the Federal Technologic University of Parana (UTFPR-DV). Four species of cover crops were used, namely: Avena strigosa, Cichorium intybus, Chenopodium quinoa and Fagopyrum esculentum, from which the extract was retrieved. The extracts were applied on milkweed seeds. The seeds of E. heterophylla were collected in several crops in the municipality of Dois Vizinhos, PR. After being collected, they were left to dry in shade until the capsular rupture (Suda and Giorgini, 2000), and the mature seeds were stored in a cold chamber until the germination test. The identification was carried out in the herbarium of the Federal Technologic University of Parana.

To prepare the extracts, the ground cover plant seeds were sown in the field and, 75 days after emergence, the aerial part was collected. The collected material was left to dry in a forced air oven for 120 hours at $\pm 45^{\circ} \mathrm{C}$. The low temperature during the drying process is necessary to minimize the loss of volatile substances. After drying, the aerial part of the materials was grounded in a razor type mill, in a $4 \mathrm{~mm}$ mesh sieve.

The extracts were prepared in $10 \%$ weight/volume concentration, based on the dry matter content. The grounded materials were immersed in distilled water, in glass beakers, closed with plastic film and covered with black plastic to avoid light incidence, for 24 hours at room temperature, according to the methodology presented by Belel and Belel (2015).

After, the crude extract was filtered on filter paper to remove coarse particles, and then the dilutions in distilled water were performed, according to the treatments $(1 \%, 2.5 \%, 5 \%$ and $10 \%)$, being the control treatment $(0 \%)$ with distilled water.

The experimental design was completely randomized, in a $4 \times 5$ factorial scheme with four repetitions. Where factor A-were the aqueous extracts of the cover crops (oat, forage chicory, quinoa and buckwheat). Factor B- $0 \%$, $1 \%, 2.5 \%, 5 \%$ and $10 \%$ concentrations of aqueous extract from cover crops. 
For the germination of E. heterophylla seeds, 25 seeds were used, disposed in gerboxes, containing two sheets of germination paper, then $15 \mathrm{~mL}$ of extract were added according to the treatments. The germination test was performed in a growth chamber (BOD) with a photoperiod of 12/12 light/dark hours at constant temperature of $25^{\circ} \mathrm{C}$.

The evaluations were carried out daily by counting the number of germinated seeds. We considered as germinated seeds that had radicle protrusion. After collecting these data, the percentage of germination, the GSI (germination speed index), average germination time, the length and dry green mass of the aerial and root parts were assessed.

The data obtained in the laboratory were analyzed regarding their homogeneity and subjected to analysis of variance through the $\mathrm{F}$ test, and, in case of statistical significance, a comparison was made between averages; for the cover crop factor, the Tukey test $(\mathrm{p} \leq 0.05)$ was used, and, for the extract concentration factor, regression analysis was used.

\section{Results and Discussion}

For the germination percentage variable and the germination speed index of the milkweed, there was interaction between the cover crop and extract dosage factors (Tables 1 and 2).

Regarding the control ( $0 \%$ extract) and the other concentrations of the aqueous extract of different covers, only the buckwheat showed no difference between the concentrations on the percentage of germination and the germination speed index of milkweed.

Table 1. Percentage of germination $(\% \mathrm{G})$ of Euphorbia heterophylla under different concentrations of cover plants aqueous extracts

\begin{tabular}{llllll}
\hline \multirow{2}{*}{ Extracts } & \multicolumn{5}{c}{ Concentrations } \\
\cline { 2 - 6 } & $0 \%$ & $1 \%$ & $2.5 \%$ & $5 \%$ & $10 \%$ \\
\hline Oats & $95.00 \mathrm{a}$ & $93.00 \mathrm{a}$ & $85.00 \mathrm{a}$ & $90.00 \mathrm{a}$ & $78.00 \mathrm{ab}$ \\
Forage chicory & $95.00 \mathrm{a}$ & $95.00 \mathrm{a}$ & $82.00 \mathrm{a}$ & $92.00 \mathrm{a}$ & $68.00 \mathrm{~b}$ \\
Quinoa & $95.00 \mathrm{a}$ & $91.00 \mathrm{a}$ & $90.00 \mathrm{a}$ & $85.00 \mathrm{a}$ & $17.00 \mathrm{c}$ \\
Buckwheat & $95.00 \mathrm{a}$ & $92.00 \mathrm{a}$ & $89.00 \mathrm{a}$ & $91.00 \mathrm{a}$ & $90.00 \mathrm{a}$ \\
\hline
\end{tabular}

Note. 1 Values followed by the same letter in the column do not differ statistically by the Tukey $(\mathrm{P}<0.05)$ test.

Table 2. Germination speed index (GSI) of Euphorbia heterophylla under different concentrations of aqueous extract of cover plants

\begin{tabular}{llllll}
\hline \multirow{2}{*}{ Extratos } & \multicolumn{5}{c}{ Concentrations } \\
\cline { 2 - 6 } & $0 \%$ & $1 \%$ & $2.5 \%$ & $5 \%$ & $10 \%$ \\
\hline Oats & $46.20 \mathrm{a}^{1}$ & $44.82 \mathrm{a}$ & $42.11 \mathrm{a}$ & $32.05 \mathrm{a}$ & $35.63 \mathrm{ab}$ \\
Forage chicory & $46.20 \mathrm{a}$ & $48.86 \mathrm{a}$ & $37.87 \mathrm{a}$ & $39.53 \mathrm{a}$ & $26.96 \mathrm{~b}$ \\
Quinoa & $46.20 \mathrm{a}$ & $47.23 \mathrm{a}$ & $47.04 \mathrm{a}$ & $37.27 \mathrm{a}$ & $5.72 \mathrm{c}$ \\
Buckwheat & $46.20 \mathrm{a}$ & $48.72 \mathrm{a}$ & $44.42 \mathrm{a}$ & $41.96 \mathrm{a}$ & $42.79 \mathrm{a}$ \\
\hline
\end{tabular}

Note. Values followed by the same letter the column do not differ statistically by the Tukey $(\mathrm{P}<0.05)$ test.

After analyzing each extract, only the larger dose (10\%) showed significant difference between the extracts of the cover plants. The quinoa extract provided the lowest percentage of germination, that is, a $2 \%$ reduction of this variable in relation to the control. The milkweed germination speed index (GSI) was reduced by $87 \%$ compared to the control, differentiating itself from oats, chicory and buckwheat.

In the studies conducted by Fedrigo et al. (2010) with aqueous extracts of Chenopodium quinoa Willd., a saponin substance was found. Saponin is derived from secondary metabolism and are connected to the defense system of the plants that produced them (Wina et al., 2005). In other study, El-Sadek et al. (2017), in another study, found that five different quinoa materials had an allelopathic effect on the germination of crops and weeds. Qualitative-quantitative analysis, according to the authors, showed sixteen flavonoids and three hydroxicinnamic acids (p-coumaroyl derivatives) 
When comparing the different concentrations of aqueous extract, the quinoa obtained the best result with the larger dose, reducing the germination speed index $(<10)$ (Figure 3a) and the percentage of germination (Figure $3 b)$ of milkweed seeds $(<20 \%)$, showing high allelopathic potential to this weed.
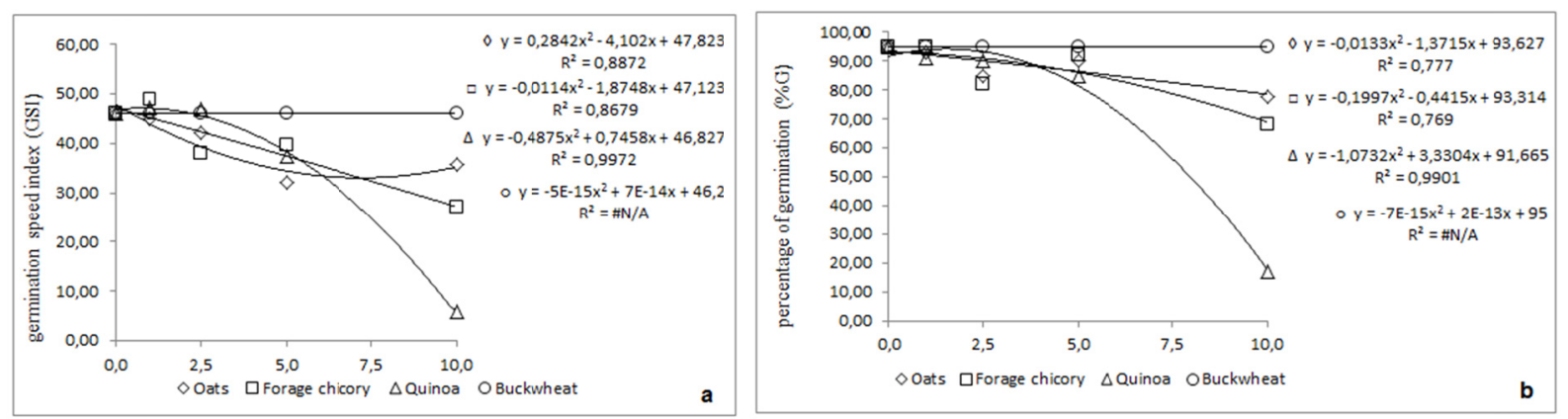

Figure 3. Germination speed index (GSI) and germination percentage $(\% \mathrm{G})$ of Euphorbia heterophylla regarding the aqueous extracts of $\diamond$ oats, $\square$ forage chicory, $\Delta$ quinoa and $\circ$ buckwheat, under different concentrations

Regarding weeds, the lower the average germination speed, the more favorable for the reduction of the competition with the crop, that is, the crop can take advantage in the competitive process. In Table 3 , an interaction can be observed between the extracts and concentrations tested. When compared to different extract concentration to each cover plant, it can be observed that the chicory and quinoa extract increased the average germination time of milkweed seeds, differing in the $10 \%$ concentrations (Table 3 ). In the highest concentration regarding the control, the chicory extract increased the average germination time in $88 \%$, and the quinoa extract in $140 \%$. The increase in average germination time leads to the delay of the establishment of weeds regarding the culture to be established in the crop area, being characterized as a favorable point in weed management.

Table 3. Average germination time (AGT) $\left(\right.$ days $\left.^{-1}\right)$ of Euphorbia heterophylla under difference concentrations of aqueous extracts of cover plants, UTFPR, Dois Vizinhos, 2017

\begin{tabular}{llllll}
\hline \multirow{2}{*}{ Extracts } & \multicolumn{5}{c}{ Concentrations } \\
\cline { 2 - 6 } & $0 \%$ & $1 \%$ & $2.5 \%$ & $5 \%$ & $10 \%$ \\
\hline Oats & $2.11 \mathrm{a}^{1}$ & $1.85 \mathrm{a}$ & $1.98 \mathrm{a}$ & $2.99 \mathrm{a}$ & $2.26 \mathrm{c}$ \\
Forage chicory & $2.11 \mathrm{a}$ & $2.19 \mathrm{a}$ & $2.74 \mathrm{a}$ & $3.07 \mathrm{a}$ & $3.98 \mathrm{~b}$ \\
Quinoa & $2.11 \mathrm{a}$ & $2.45 \mathrm{a}$ & $2.30 \mathrm{a}$ & $3.33 \mathrm{a}$ & $5.08 \mathrm{a}$ \\
Buckwheat & $2.11 \mathrm{a}$ & $2.17 \mathrm{a}$ & $2.71 \mathrm{a}$ & $2.97 \mathrm{a}$ & $3.04 \mathrm{bc}$ \\
\hline
\end{tabular}

Note. Values followed by the same letter in the column do not differ statistically by the Tukey $(\mathrm{P}<0.05)$ test.

When comparing the different extracts, the highest concentration $(10 \%)$ gave the quinoa extract an increase in average germination time, differing from chicory, buckwheat and oat, respectively (Table 3).

Concerning the average germination speed (Figure 4b), the quinoa extract was the one that most interfered in the variable. The higher the concentration, the lower the germination speed of milkweed seeds. The average germination time (Figure 4a) was affected by the quinoa extract as the concentrations of the extract increased. 

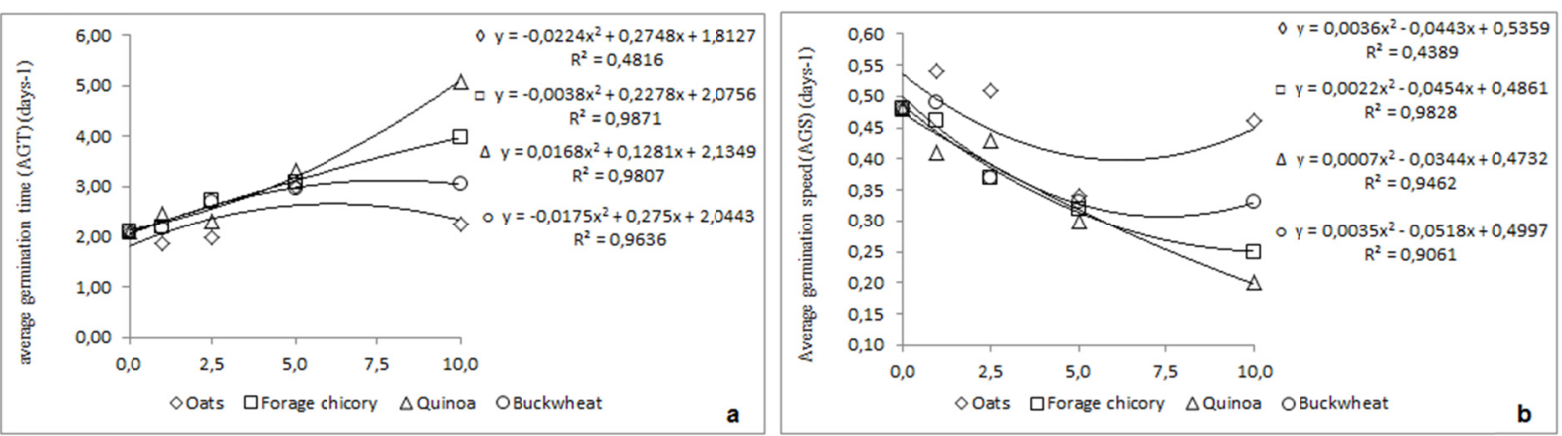

Figure 4. Average germination speed (AGS) $\left(\right.$ days $\left.^{-1}\right)$ and the average germination time (AGT) $\left(\right.$ days $\left.^{-1}\right)$ of Euphorbia heterophylla regarding the aqueous extracts of $\diamond$ oat, $\square$ forage chicory, $\Delta$ quinoa and $\circ$ buckwheat under different concentrations

For the variable length of the aerial and root part (Tables 4 and 5) of milkweed, there was an interaction between the different aqueous extracts and their concentrations (Table 4). Comparing the control (0\%) with the highest dose $(10 \%)$, all the extracts of the tested species reduced the length of the aerial and root part of the milkweed. The quinoa extract interfered the most in the length of the aerial part, reducing this variable by $99.5 \%$ in the $10 \%$ concentration, followed by chicory, buckwheat and oats. The quinoa, from the lowest dose, reduced the aerial part length in $44 \%$, showing its allelopathic potential on the variable.

Table 4. Aerial part length (mm) of Euphorbia heterophylla under different concentrations of aqueous extracts of cover plants

\begin{tabular}{llllll}
\hline \multirow{2}{*}{ Extracts } & \multicolumn{5}{c}{ Concentrations } \\
\cline { 2 - 6 } & $0 \%$ & $1 \%$ & $2.5 \%$ & $5 \%$ & $10 \%$ \\
\hline Oats & $46.22 \mathrm{a}^{1}$ & $72.17 \mathrm{a}$ & $63.57 \mathrm{a}$ & $44.22 \mathrm{a}$ & $36.72 \mathrm{a}$ \\
Forage chicory & $46.22 \mathrm{a}$ & $67.94 \mathrm{a}$ & $31.13 \mathrm{c}$ & $27.45 \mathrm{~b}$ & $8.20 \mathrm{c}$ \\
Quinoa & $46.22 \mathrm{a}$ & $25.85 \mathrm{~b}$ & $12.52 \mathrm{~d}$ & $11.33 \mathrm{c}$ & $0.22 \mathrm{~d}$ \\
Buckwheat & $46.22 \mathrm{a}$ & $72.15 \mathrm{a}$ & $54.27 \mathrm{~b}$ & $28.82 \mathrm{~b}$ & $18.80 \mathrm{~b}$ \\
\hline
\end{tabular}

Note. Values followed by the same lower-case letter in the row and by a capital letter in the column do not differ statistically by the Tukey $(\mathrm{P}<0.05)$ test.

The root length (Table 5) was more affected than the aerial part length, and, in general, differences occurred from $1 \%$ concentration of the extracts. The chicory, quinoa and buckwheat extracts completely inhibited the root part with this concentration (10\%). The quinoa, from $2.5 \%$, completely inhibited the root development.

When compared to the cover plants in each concentration, the quinoa, in $1 \%, 2.5 \%$ and $5 \%$ doses, reduced this variable more efficiently than the others (Table 5).

Table 5. Root length (mm) of Euphorbia heterophylla under different concentrations of aqueous extracts of cover plants

\begin{tabular}{llllll}
\hline \multirow{2}{*}{ Extracts } & \multicolumn{5}{c}{ Concentrations } \\
\cline { 2 - 6 } & $0 \%$ & $1 \%$ & $2.5 \%$ & $5 \%$ & $10 \%$ \\
\hline Oats & $78.50 \mathrm{a}^{1}$ & $47.92 \mathrm{~b}$ & $53.05 \mathrm{a}$ & $27.50 \mathrm{a}$ & $10.40 \mathrm{a}$ \\
Forage chicory & $78.50 \mathrm{a}$ & $40.37 \mathrm{~b}$ & $19.66 \mathrm{c}$ & $22.97 \mathrm{a}$ & $0.00 \mathrm{~b}$ \\
Quinoa & $78.50 \mathrm{a}$ & $6.67 \mathrm{c}$ & $0.00 \mathrm{~d}$ & $0.00 \mathrm{c}$ & $0.00 \mathrm{~b}$ \\
Buckwheat & $78.50 \mathrm{a}$ & $71.70 \mathrm{a}$ & $38.27 \mathrm{~b}$ & $11.65 \mathrm{~b}$ & $0.00 \mathrm{~b}$ \\
\hline
\end{tabular}

Note. Values followed by the same letter in the column do not differ statistically by the Tukey $(\mathrm{P}<0.05)$ test.

It was observed, when analyzing the lengths of the aerial (Figure 5a) and root (Figure 5b) parts of different extracts regarding the concentrations, that, as the dose increases, the greater is the effect on the variables tested 
to all extracts. The quinoa extract showed the most accentuated interference in both variables, and the oat extract showed the lowest.
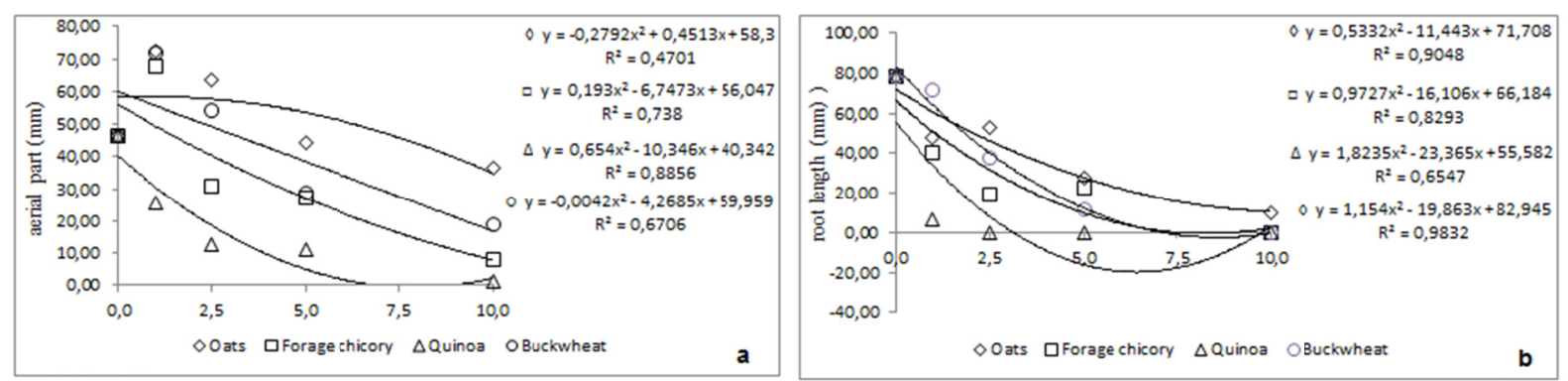

Figure 5. Aerial part ( $\mathrm{mm})$ and root length $(\mathrm{mm})$ of the Euphorbia heterophylla regarding the aqueous extracts of $\diamond$ oat, $\square$ forage chicory, $\Delta$ quinoa and $\circ$ buckwheat, under different concentrations

For the green mass of the aerial and root parts variables (Tables 6 and 7), there were interactions between aqueous extracts of cover plants and the different concentrations in them. Regarding the different extract, from the lowest concentration, the quinoa obtained lower green mass weight of the milkweed aerial part, reducing $97 \%$ in the highest dose, differing from chicory, oat and buckwheat.

Table 6. Aerial part green mass (mg) of the Euphorbia heterophylla under different concentrations of aqueous extracts of cover plants

\begin{tabular}{llllll}
\hline \multirow{2}{*}{ Extracts } & \multicolumn{5}{c}{ Concentrations } \\
\cline { 2 - 6 } & $0 \%$ & $1 \%$ & $2.5 \%$ & $5 \%$ & $10 \%$ \\
\hline Oats & $34.58 \mathrm{a}^{1}$ & $30.08 \mathrm{~b}$ & $26.25 \mathrm{a}$ & $20.58 \mathrm{~b}$ & $24.21 \mathrm{ab}$ \\
Forage chicory & $34.58 \mathrm{a}$ & $37.99 \mathrm{a}$ & $30.74 \mathrm{a}$ & $11.12 \mathrm{c}$ & $19.00 \mathrm{~b}$ \\
Quinoa & $34.58 \mathrm{a}$ & $11.75 \mathrm{c}$ & $13.42 \mathrm{~b}$ & $11.26 \mathrm{c}$ & $0.91 \mathrm{c}$ \\
Buckwheat & $34.58 \mathrm{a}$ & $42.91 \mathrm{a}$ & $33.10 \mathrm{a}$ & $32.94 \mathrm{a}$ & $32.01 \mathrm{a}$ \\
\hline
\end{tabular}

Note. Values followed by the same letter in the column do not differ statistically by the Tukey $(\mathrm{P}<0.05)$ test.

For the root green mass variable, in the highest concentration, only oat differed from the other extracts, with less interference in the development of milkweed root. The chicory and buckwheat did not provide the development of the weed root system (Table 7).

Table 7. Root green mass (mg) of Euphorbia heterophylla under different concentrations of aqueous extracts of cover plants

\begin{tabular}{llllll}
\hline \multirow{2}{*}{ Extracts } & \multicolumn{5}{c}{ Concentrations } \\
\cline { 2 - 6 } & $0 \%$ & $1 \%$ & $2.5 \%$ & $5 \%$ & $10 \%$ \\
\hline Oats & $16.56 \mathrm{a}^{1}$ & $6.42 \mathrm{~b}$ & $12.18 \mathrm{a}$ & $6.74 \mathrm{a}$ & $4.31 \mathrm{a}$ \\
Forage chicory & $16.56 \mathrm{a}$ & $9.20 \mathrm{a}$ & $5.95 \mathrm{~b}$ & $4.47 \mathrm{~b}$ & $0.00 \mathrm{~b}$ \\
Quinoa & $16.56 \mathrm{a}$ & $9.48 \mathrm{a}$ & $0.00 \mathrm{c}$ & $0.00 \mathrm{c}$ & $0.00 \mathrm{~b}$ \\
Buckwheat & $16.56 \mathrm{a}$ & $4.06 \mathrm{c}$ & $10.36 \mathrm{a}$ & $7.83 \mathrm{a}$ & $0.00 \mathrm{~b}$ \\
\hline
\end{tabular}

Note. Values followed by the letter in the column do not differ statistically by the Tukey $(\mathrm{P}<0.05)$ test.

Roots are more sensitive to allelochemicals than aerial parts of seedlings (Ercoli et al. 2007), probably because it is the first plant organ that comes in contact with the differents allelochemical.

When studying the composition of the hydroalcoholic extract of Cichorium intybus leaves, it was found that they have total flavonoids, total phenolic acids, tannins, saponins, flavonoids (Abbas et al., 2015). Many of these compounds are associated to the defense (allelochemicals) of the plant that produces them. 
The buckwheat extract obtained greater effect in the roots. The plant contains flavonoids associated to allelopathic effects, but other compounds are part of their structure, such as isoquercitrin, keratin, catechin and myricetin, which can potentialize the allelopathic capacity in some weeds (Kalinova \& Vrchotova, 2009).

Analyzing Figure 6a, the quinoa extract obtained best results regarding the green matter mass variable of milkweed, because, as the concentration of extract increased, the matter decreased. The buckwheat extract had the least influence over the several concentrations tested, showing low allelopathic potential on this variable. As for the root green mass (Figure 6b), the buckwheat showed effect, as well as the chicory extract, in which, in the largest concertation, the root green mass was zero.

Such results show that each cover crop has allelopathic action in different parts of the plant, in which the the buckwheat had no allelopathic effect on the aerial part, but on the milkweed root.

In this sense, the allelopathic potential of oat extracts (Avena sativa L.) was investigated by Kato-Noguchi (1994), who observed that oat sprout extracts inhibited the germination and growth of lettuce (Lactuca sativa L.) roots and hypocotyls, in which an active principle was isolated and determined as tryptophan.

However, such allelopathic effects of oat regarding the E. heterophylla weed were not expressive or were smaller than the quinoa, chicory and buckwheat extracts in all variables tested.
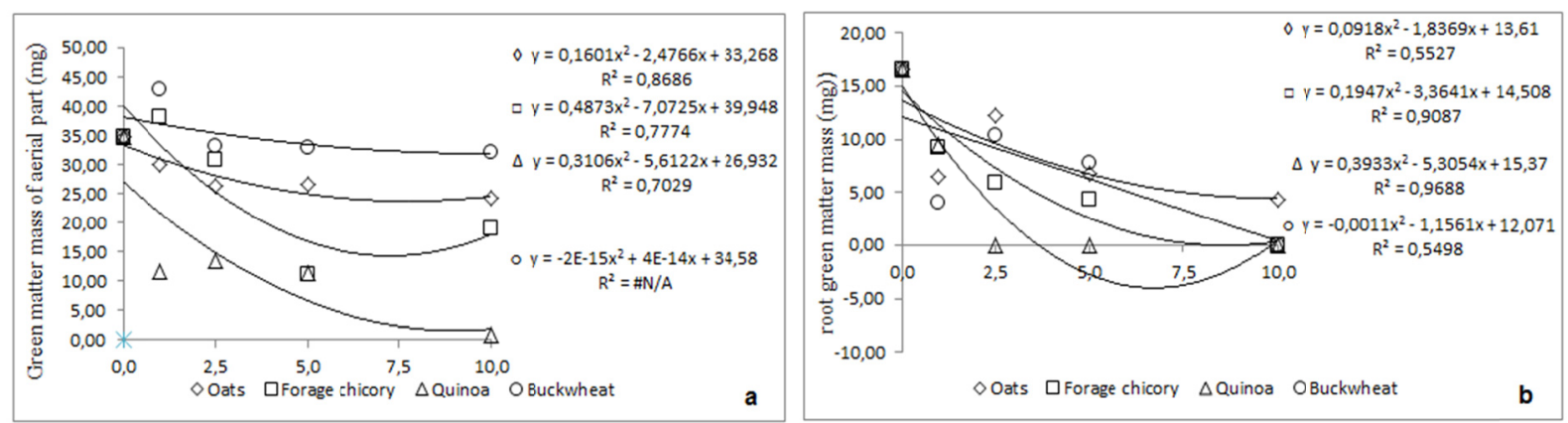

Figure 6. Green matter mass of aerial part (mg) and root green matter mass (mg) of Euphorbia heterophylla regarding the aqueous extracts of $\diamond$ oat, $\square$ forage chicory, $\Delta$ quinoa and $\circ$ buckwheat

In general, the quinoa aqueous extract at the highest concentration (10\%) showed allelopathic potential than the other extracts tested, interfering in the variables: percentage of germination, germination speed index, average germination speed, average germination time, aerial part length and green mass of the aerial part of Euphorbia heterophylla. El-Sadek et al. (2017), also observed that extracts of quinoa have expressive effects on monocotiledoe and dicotyledonous, but with more promising results on monocotyledonous plants.

The quinoa and forage chicory extracts have allelopathic potential, interfering mainly in the Euphorbia heterophylla root.

\section{Conclusion}

The quinoa was the ground cover plant that most inhibited the Euphorbia heterophylla germination and initial growth, and the effect was greatest as the extract doses were increased.

\section{References}

Abbas, Z. K., Saggu, S., Sakeran, M., Zidan, N., Rehman, H., \& Ansari, A. A. (2015). Phytochemical, antioxidant and mineral composition of hydroalcoholic extract of chicory (Cichorium intybus L.) leaves. Saudi Journal of Biological Sciences, 22(3), 322-326. https://doi.org/10.1016/j.sjbs.2014.11.015

El-Sadek, A., Mohamed, B., Annalisa R., Francesca I., Vignolini, P., Salem, E., ... Virtuosi, I. (2017). Allelopathic potential of Quinoa (Chenopodium quinoa Willd.) genotypes on the germination and initial development of some weeds and crops. Egyptian J. Desert Res., 67(1), 25-45. https://doi.org/10.21608/ ejdr.2017.5843

Ercoli, L., Masoni, A., Pampana, S., \& Arduini, I. (2007). Allelopathic effects of rye, brown mustard and hairyn vetch on redroot pigweed, common lambsquarter and knotweed. Allelopathy Journal, 19, 249-256. 
Fedrigo, I. H., Borgo, A. P., Baggio, F. R., Musial, D. C., \& Valentini, S. A. (2010). Production of cosmetics from the aqueous extract of quinoa (Chenopodium quinoa Willd.). Saúde e Pesquisa, 4(2), 207-212.

Filho, A. P. S. S. (2002). Allelopathy: From the first observations to the current concepts. Allelopathy: Basic principles and general aspects (pp. 15-23). Belém: Embrapa Amazônia Oriental.

Filho, A. P. S. S., \& Alves, S. M. de. (2002). Mechanisms of release and behavior of allelochemicals in the environment. Allelopathy: Basic principles and general aspects (pp. 112-129). Belém: Embrapa Amazônia Oriental.

Gabius, H. J., André, S., Kaltner, H., \& Siebert, H. C. (2002). The sugar code: Functional lectinomics. Biochimica et Biophysica Acta-General Subjects, 1572(2-3), 165-177. https://doi.org/10.1016/ S0304-4165(02)00306-9

Hagemann, T. R., Benin, G., Lemes, C., Marchese, J. A., Martin, T. N., Pagliosa, E. S., \& Beche, E. (2010). Effect of extracts from the above-ground part of oat genotypes on ryegrass and wild poinsettia. Bragantia, 69(3), 509-518. https://doi.org/10.1590/S0006-87052010000300001

Kalinova, J., \& Vrchotova, N. (2009). Level of catechin, myricetin, quercetin and isoquercitrin in buckwheat (Fagopyrum esculentum Moench), changes of their levels during vegetation and their effect on the growth of selected weeds. Journal of Agricultural and Food Chemistry, 57(7), 2719-2725. https://doi.org/ $10.1021 / \mathrm{jf} 803633 \mathrm{f}$

Kato-Noguchi, H., Kosemura, S., Yamamura, S., Mizutani, J., \& Hasegawa, R. (1994). Allelopathy of oats. I. Assessment of allelopathic potential of extract of oat shoots and identification of an allelochemical. Journal of Chemical Ecology, 20(2), 309-314. https://doi.org/10.1007/BF02064439

Lamego, F. P., Kaspary, T, E., Ruchel, Q., Gallon, M., Basso, C. J., \& Santi, A. C. (2013). Management of glyphosate resistant Conyza bonariensis: Winter cover crops and herbicides in soybean pre-seeding. Planta Daninha, 31(2), 433-442. https://doi.org/10.1590/S0100-83582013000200022

Melo, A. C., \& Souto, J. S. (2011). Capacity of land use in laying patativa of Assaré, Patos-PB. Revista de Geografia UFPE.

Monteiro, C. A., \& Vieira, E. L. (2002). Allelopathic substances. In P. R. C. Castro, J. O. A. Sena, \& R. A. Kluge (Eds.), Introduction to the physiology of plant development (pp. 105-122). Maringá: EDUEM.

Oliveira, R. A., Park, K. J., Chiorato, M., Park, K. J. B., \& Nogueira, R. J. (2004) Optimization of inulin extraction from chicory roots. Revista Brasileira de Produtos Agroindustriais, 6(2), 140. https://doi.org/ 10.15871/1517-8595/rbpa.v6n2p131-140

Pacheco, L. P., Pires, F. R., Monteiro, F. P., Procópio, S. O., Assis, R. L., Cargnelutti Filho, A. ... Petter, F. A. (2009). Soybean crop oversowing used as a technique to suppress weed emergence. Planta Daninha, 27(3), 455-463. https://doi.org/10.1590/S0100-83582009000300005

Rizzardi, M. A., \& Silva, L. F. (2006). Influence of black oats and rape as cover crops on chemical weed control timing in no-till corn. Planta Daninha, 24(4), 669-675. https://doi.org/10.1590/S0100-83582006000400007

Sytar, O., Barankulova, A., Hemmerich, I., Rauh, C., \& Smetanska, I. (2014). Effect of chlorocholine chlorid on phenolic acids accumulation and polyphenols formation of buckwheat plants. Biological Research, 47, 1-7. https://doi.org/10.1186/0717-6287-47-19

Suda, C. N. K., \& Giorgini, J. F. (2000). Seed reserve composition and mobilization during germination and initial seedling development of Euphorbia heterophylla. Revista Brasileira de Fisiologia Vegetal, 12(3), 226-245. https://doi.org/10.1590/S0103-31312000000300006

Trezzi, M. M., \& Vidal, R. A. (2004). Potential of sorghum and pearl millet cover crops in weed supression in the field: II - Mulching effect. Planta Daninha, 2(1), 1-10.

Valencia, Z., Cámara, F., Ccapa, K., Catacova, P., \& Quispe, F. (2017). Bioactive compounds and antioxidant activity from Peruvian quinoa seeds (Chenopodium quinoa W.). Revista de la Sociedad Química del Perú, 83(1), 16-29.

Voll, E., Gazziero, D. L. P., Brigheti, A. M., Adega, F. S., Gaudêncio, C. De A., \& Voll, A. A. (2008). Weeds: The seed bank and the sustainabllity of technologies in soybean croppings. Londrina: Embrapa Soja. 
Wina, E., Muetzel, S., \& Becker, K. (2005). The Impact of Saponins or Saponin-Containing Plant Materials on Ruminant Production-A Review. Journal of Agricultural and Food Chemistry, 53(21), 8093-8105. https://doi.org/10.1021/jf048053d

\section{Copyrights}

Copyright for this article is retained by the author(s), with first publication rights granted to the journal.

This is an open-access article distributed under the terms and conditions of the Creative Commons Attribution license (http://creativecommons.org/licenses/by/4.0/). 